\title{
Effect of Insulin on Glucagon Enhanced Lipolysis in Vitro*
}

\author{
P.J. Lefebrre and A.S. LuYokX
}

Institut de Médecine, Département de Clinique et de Pathologie Médicales, Secteur Diabétologie, Université de Liège, Belgique

Received: June 16, 1968

Summary. Glucagon in concentrations similar to those found in human plasma markedly stimulates lipolysis in rat adipose tissue in vitro. The effects of these "physiological" concentrations of glucagon are reduced or abolished by insulin at concentrations of 25 and $100 \mu \mathrm{U} / \mathrm{ml}$. Considering the marked insulinogenic effect of glucagon these observations may provide an explanation for the delayed increase of blood FFA observed after glucagon injection in vivo. in vitro

Effet de l'insuline sur la lipolyse induite par le glucagon

Résumé. A des concentrations proches de celles qui sont rencontrées dans le plasma humain, le glucagon stimule fortement la lipolyse au niveau de la graisse épididymaire du rat, étudiée in vitro. Les effets de telles concentrations de glucagon sont réduits, voire abolis par l'insuline aux concentrations de 25 et $100 \mu \mathrm{U} / \mathrm{ml}$. Rapprochées de l'effet insulinogénique puissant du glucagon, ces observations peuvent fournir une explication quant au caractère retardé de l'élévation du taux sanguin des acides gras libres observée après injection de glucagon in vivo.

Wirkung von Insulin auf die glucagon-induzierte Lipolyse in vitro

Zusammenfassung. Glucagon stimuliert in Konzentrationen, wie sie auch im menschlichen Plasma vorkommen, die Lipolyse im $\mathbb{R}$ atten-Nebenhodenfettgewebe in vitro stark. Die Effekte derartiger Glucagonkonzentrationen werden durch Insulin $(25-100 \mu \mathrm{E} / \mathrm{ml})$ verringert bis aufgehoben. Unter Berücksichtigung der ausgeprägten Wirkung von Glucagon auf die Insulinfreisetzung können diese Beobachtungen eine Erklärung für die Verzögerung des Anstiegs der freien Fettsäuren im Serum liefern, die man nach Glucagoninjektionen in vivo beobachtet. FFA.

Keys words: Insulin, glucagon, adjpose tissue, lipolysis,

\section{Material and Methods}

Male albino rats of the Wistar strain, weighing $160-180 \mathrm{~g}$ and fasted $12-14 \mathrm{~h}$ were used. The animals were killed by decapitation, and the epididymal fad pads were removed rapidly according to the technique of RENoLD et al. [13]. Pieces of tissue weighing 120$140 \mathrm{mg}$ were incubated for $4 \mathrm{~h}$ in $4 \mathrm{ml}$ of a modified [13] Krebs-Ringer bicarbonate buffer containing 3\% human albumin (Fraction V, Armour Co). Glucose was present at the concentration of 100 or $300 \mathrm{mg} \%$. Ten times recrystallized, bovine insulin and cystein-treated glucagon (insulin contamination $0.002 \%$ ) were obtained through the courtesy of Dr. Sohlichrckrutu, Novo Industri A.S. Copenhagen, Denmark, and used at the concentrations of 0,25 , and $100 \mu \mathrm{U} / \mathrm{ml}$, and of $0,0.002$, 0.005 and $0.010 \mu \mathrm{g} / \mathrm{mI}$, respectively. Aliquots of the medium were taken for glycerol analysis by an enzymatic procedure [4].

\section{Results}

The results are summarized in Tables 1 and 2 .

1. In the presence of glucose at a concentration of $100 \mathrm{mg} \%$ and in the absence of insulin, concentrations as small as $0.002 \mu \mathrm{g} / \mathrm{ml}$ of glucagon stimulated lipolysis as tested by glycerol release. This stimulating effect of glucagon was reduced by insulin at a concentration of $25 \mu \mathrm{U} / \mathrm{ml}$. At this concentration the effect of 0.002 $\mu \mathrm{g} / \mathrm{ml}$ of glucagon was abolished; the effects of 0.005 and $0.010 \mu \mathrm{g} / \mathrm{ml}$, although reduced, remained statisti-

\footnotetext{
* This work was supported by the "Fonds National de la Recherche Scientifique" and the "Fonds de la Recher. che Scientifique Médicale", Belgium.
} 
cally significant. At the concentration of $100 \mu \mathrm{U} / \mathrm{ml}$, insulin abolished the effect of glucagon at all concentrations tested.

Table 1. Effects of insulin on the lipolytic action of glucagon in the presence of $100 \mathrm{mg} \%$ glucose

\begin{tabular}{|c|c|c|c|}
\hline $\begin{array}{l}\text { Tnsulin } \\
\mu \mathrm{U} / \mathrm{ml}\end{array}$ & $\begin{array}{l}\text { Glucagon } \\
\mu \mathrm{g} / \mathrm{ml}\end{array}$ & $\begin{array}{l}\text { Glycerol release } \\
\mu \mathrm{M} / g / 4 \mathrm{~h}^{\mathrm{a}}\end{array}$ & $p$ \\
\hline $\mathbf{0}$ & 0 & $5.19+0.39(22)$ & - \\
\hline 0 & 0.002 & $11.01 \pm 1.00(12)$ & $<0.01$ \\
\hline 0 & 0.005 & $22.84 \pm 3.35(6)$ & $<0.01$ \\
\hline 0 & 0.010 & $20.25 \pm 2.37$ & $<0.01$ \\
\hline 25 & 0 & $3.87 \pm 0.87$ & - \\
\hline 25 & 0.002 & $3.86 \pm 0.44$ (6) & N.S. \\
\hline 25 & 0.005 & $6.26 \pm 0.46 \quad(6)$ & $<0.01$ \\
\hline 25 & 0.010 & $5.83 \pm 0.47$ & $<0.01$ \\
\hline 100 & 0 & $4.86 \pm 0.28$ & - \\
\hline 100 & 0.002 & $4.73 \pm 0.21 \quad(6)$ & N.S. \\
\hline 100 & 0.005 & $4.54 \pm 0.18$ & N.S. \\
\hline 100 & 0.010 & $4.90 \pm 0.14$ & N.10. \\
\hline
\end{tabular}

a Mean \pm Standard Error of the Mean, the number of determinations is indicated in parentheses.

Table 2. Effects of insulin on the lipolytic action of glucagon in the presence of $300 \mathrm{mg} \%$ glucose

\begin{tabular}{|c|c|c|c|}
\hline $\begin{array}{l}\text { Insulin } \\
\mu \mathrm{U} / \mathrm{ml}\end{array}$ & $\begin{array}{l}\text { Glucagon } \\
\mu \mathrm{g} / \mathrm{ml}\end{array}$ & $\begin{array}{l}\text { Glycerol release } \\
\mu \mathrm{M} / \mathrm{g} / 4 \mathrm{~h}^{\mathrm{a}}\end{array}$ & $p$ \\
\hline 0 & 0 & $5.98 \pm 0.42(11)$ & - \\
\hline 0 & 0.002 & $7.15 \pm 1.41(12)$ & N.S. \\
\hline 0 & 0.005 & $9.09 \mp 1.28(12)$ & $<0.05$ \\
\hline 0 & 0.010 & $12.20 \pm 2.20(12)$ & $<0.02$ \\
\hline 25 & 0 & $4.82 \pm 0.30$ & - \\
\hline 25 & 0.002 & $5.39 \pm 0.30 \quad(6)$ & N.S. \\
\hline 25 & 0.005 & $7.52+0.99$ & $<0.05$ \\
\hline 25 & 0.010 & $8.26 \pm 0.76$ & $<0.01$ \\
\hline 100 & 0 & $4.34 \pm 0.20(12)$ & - \\
\hline 100 & 0.002 & $4.40 \pm 0.20(12)$ & N.S. \\
\hline 100 & 0.005 & $5.45 \mp 0.32(12)$ & $<0.02$ \\
\hline 100 & 0.010 & $6.99 \pm 0.57(12)$ & $<0.01$ \\
\hline
\end{tabular}

a Mean \pm Standard Exror of the Mean, the number of determinations is indicated in parentheses.

2. In the presence of glucose at a concentration of $300 \mathrm{mg} \%$, glucagon enhanced lipolysis when added in concentrations of 0.005 and $0.010 \mu \mathrm{g} / \mathrm{ml}$. These concentrations remained effective even in the presence of 25 or $100 \mu \mathrm{U} / \mathrm{ml}$ of insulin, although the effect was reduced.

\section{Discussion}

It is still hazardous to define the normal range of plasma glucagon concentration levels on the basis of the available data obtained by radioimmunoassay [19]. It has been reported that basal levels in man range from $200 \mu \mu \mathrm{g} \mathrm{Eq} / \mathrm{ml}$ to $8000 \mu \mu \mathrm{g} \mathrm{Eq} / \mathrm{ml}[17,6,21,15$, $11,18]$, with most values between 500 and $2000 \mu \mu \mathrm{g}$ $\mathrm{Eq} / \mathrm{ml}$. Values up to $20000 \mu \mu \mathrm{g} \mathrm{Eq} / \mathrm{ml}$ have been reported in various clinical conditions [6], and very high values of 36000 and $55000 \mu \mu \mathrm{gq} / \mathrm{ml}$ have been observed in a case of glucagonoma [12].

The present data indicate that concentrations of glucagon comparable with the concentrations of the hormone found in human plasma [recent data obtained using an antiserum "discriminating" pancreatic glucagon and gut glucagon-like immunoreactivity indicate that true concentrations of pancreatic glucagon in peripheral human plasma could be in the range of 200 to $300 \mu \mathrm{gEq} / \mathrm{ml}$ (UNGER, 1968, and HEDING, 1968, personal communications)] markedly stimulate lipolysis in incubated rat adipose tissue. The data also show that "physiological" concentrations of insulin (i.e. 25 and $100 \mu \mathrm{U} / \mathrm{ml}$ ) are able to reduce or abolish the lipolytic effects of these concentrations of glucagon. These results are not consistent with those obtained by other workers [2] using much higher concentrations of glucagon. A reduction of the lipolytic effect of glucagon has also been observed by increasing the concentration of glucose in the incubation medium from 100 to $300 \mathrm{mg}$ per cent.

These observations, correlated with the potent insulinogenic effect of glucagon, may provide an explanation for the delayed increase of blood free fatty acids observed after glucagon injection in man $[10,7]$, as well as in the dog [8]. It is possible that the lipolytic properties of glucagon injected in vivo can only be observed after the maximum hyperglycaemia and hyperinsulinaemia have subsided. However, it remains to be demonstrated that glucagon injected intravenously or intramuscularely, still exerts a lipolytic effect 2 to $4 \mathrm{~h}$ after its injection, when the increase in blood FFA is observed.

Acknowledgements. The authors wish to acknowledge the excellent technical assistance of Mrs. BuRgutr and C. Carteinstadt.

\section{References}

1. Crockford, P.M., D. Porte Jr., F.C. Wood Jr., and R.H. WILLTAMs: Effect of glucagon on serum insulin, plasma glucose and free fatty acids in man. Metabolism $15,114-122(1966)$.

2. FaIN, J.N., V.P. Kovacev, and R.O. Scow: Antilipolytic effect of insulin in isolated fat cells of the rat. Endocrinology 78, $773-778$ (1966).

3. HAGEr, J.H.: Effects of the glucagon on the metabolism of adipose tissue. J. biol. Chem. 236, 10231027 (1960).

4. HoHonst, H.J. in: Methods of Enzymatic Analysis, ed. by H.U. BergmeYer, p. 215, New-York and London: Academic Press 1963.

5. JUNGAS, R.I., and E. G. BALL: Studies on the metabolism of adipose tissue. XII - The effect of insulin and epinephrine on free fatty acid and glycerol production in the presence and absence of glucose. Biochemistry 2, 383-388 (1963).

6. LAWRENOE, A.M.: Radioimmunoassayable glucagon levels in man: effects of starvation, hypoglycemia and glucose administration. Proc. nat. Acad. Sci. (U.S.A.) $55,316-320(1966)$.

7. LeFEBVRE, P.: Glucagon and non-esterified fatty acids (NEFA) blood levels in normal subjects. Ann. Endocr. (Paris) 26, 602-608 (1965). 
8. - Le glucagon, seconde hormone pancréatique. Paris: Maloine and Brussels: Arscia, 1967.

9. LEFEBVRE, P.J., et A.S. LUYCKX: Influence du glucagon sur le débit circulatoire pancréatico-duodénal et sur l'insulinémie du sang veineux pancréatique du chien. Arch. int. Physiol. 74, 867-876 (1966).

10. LIPSETt, M. B., H.R. Engei, and D.M. Bergerstat: Effects of glucagon on plasma unesterified fatty acids and in nitrogen metabolism. J. Lab. clin. Med. 56, $342-354$ (1960).

11. LUYCKX, A.S., and P.J. LFFERVRE : unpublished data.

12. Mo GavraN, M.H., R.H. Unger, L. Recant, H.C. Pork, C. Krro, and M. E. LitviN : A glucagon secreting alpha-cell carcinoma of the pancreas. New Engl. J. Med. 274, 1408-1413 (1966).

13. Renold, A.E., D.B. Martir, Y.M. Dagenais, J. STEINKE, R.J. NrCKERson, and M.C. SHEPs: Measurements of small quantities of insulin-like activity using rat adipose tissue. I-A proposed procedure. J. clin. Invest. 39, 1487-1498 (1960).

14. Rodbele, M., and A.B. Jones: J. biol. Chem. 241 $140-142(1966)$.

15. Samols, E., and V. Marks : Nouvelles conceptions sur la signification fonctionnelle du glucagon (pancréatique et extrapancréatique). Journées Annuelles de Diabétologie de l'Hôtel-Dieu. Paris: Flammarion 1967.

16. - G. MARRI, and V. MARKs: Promotion of insulin secretion by glucagon. Lancet 1965 II, $415-416$.

17. - J. TrLer, G. MARRI, and V. MARES: Stimulation of glucagon secretion by oral glucose. Lancet 1965 II, $1257-1259$.

18. ScHALCH, D.S.: Communication at the Research Symposium on glucagon, American Diabetes Association, San Francisco, October 7-8 (1966).

19. Sokar, J.E., and E.Z. EzDINLI: Basal plasma glucagon levels of man. J. clin. Invest. 46, 778-785 (1967).

20. TuRner, D.S., and N. MadinTrRe: Stimulation by glucagon of insulin release from rabbit pancreas in vitro. Lancet $1966 \mathrm{I}, 351-352$.

21. UNGER, R.H., and A.M. EISENTraUt: Studies of the physiologic role of glucagon. Diabetes 13, 563-568 (1964).

22. VFCCHTO, D., A. LUYCKX, G.R. ZAHND, and A.E. RENOrD : Insulin release induced by glucagon in organ cultures of fetal rat pancreas. Metabolism 15, 577$581(1966)$.

23. W EINGES, K.F.: The effect of glucagon and insulin on the metabolism of non-esterified fatty acids in isolated fatty tissue of the rat in vitro. Klin. Wschr. 39, 293298 (1961).

P.J. LeFerbveE, M.D.

A.S. LUYokx, M.D.

Institut de Médecine

Hôpital de Bavière

Liège

Belgique 